\title{
CEV MODEL WITH STOCHASTIC VOLATILITY
}

\author{
IVAN BURTNYAK, ANNA MALYTSKA
}

\begin{abstract}
This paper develops a systematic method for calculating approximate prices for a wide range of securities implying the tools of spectral analysis, singular and regular perturbation theory. Price options depend on stochastic volatility, which may be multiscale, in the sense that it may be driven by one fast-varying and one slow-varying factor. The found the approximate price of twobarrier options with multifactor volatility as a schedule for own functions. The theorem of estimation of accuracy of approximation of option prices is established. Explicit formulas have been found for finding the value of derivatives based on the development of eigenfunctions and eigenvalues of self-adjoint operators using boundary-value problems for singular and regular perturbations. This article develops a general method of obtaining a guide price for a broad class of securities. A general theory of derivative valuation of options generated by diffusion processes is developed. The algorithm of calculating the approximate price is given. The accuracy of the estimates is established. The theory developed is applied to a diffusion operator, which is decomposed by eigenfunctions and eigenvalues. The purpose of the article is to develop an algorithm for finding the approximate price of two-barrier options and to find explicit formulas for finding the value of derivatives based on the development of self-functions and eigenvalues of selfadjoint operators using boundary-value problems for singular and regular perturbations. Price finding is reduced to the problem solving of eigenvalues and eigenfunctions of a certain equation. The main advantage of our pricing methodology is that, by combining methods in spectral theory, regular perturbation theory, and singular perturbation theory, we reduce everything to equations to find eigenfunctions and eigenvalues.
\end{abstract}

Keywords: derivative pricing, stochastic volatility, local volatility, spectral theory, singular perturbation theory, regular perturbation theory.

\section{INTRODUCTION}

Spectral theory was widely used in the second half of the $20^{\text {th }}$ century by many economists. In recent years spectral analysis has become an increasingly popular tool for use in financial mathematics to analyze diffusion models which are based on the expansion of eigenfunctions and eigenvalues of linear operators. For example, it is used to find the price of a European option using Black-Scholes model [8]. Among the scientific problems that can be solved by applying spectral methods: predicting option prices, [5] securities interest rates [11], modeling the volatility of financial assets [4].

Assets estimation problems are solved analytically by methods of spectral theory [5]. Spectral theory as well as stochastic volatility models has become an indispensable tool in financial mathematics, for the matter of that, two barrier option prices are subjected to Brownian motion and are 
correlated with volatility [6]. The study of stochastic volatility, volatility assets in particular, underlies the derivative and is controlled by nonlocal diffusion.

In this article we continue the area of our research $[1 ; 2]$, expending it on the theory model CEV (constant elasticity of variance model), which was designed by John Cox in 1975, employing his methods [3; 9; 10].

Combining the methods of spectral theory and regular perturbance, we are able to calculate approximately the opportunity cost as expansion of eigenfunctions. We will work with infinitesimal generators of three-dimensional diffusion.

\section{Problem Statement}

First, consider the one-dimensional diffusion $d X_{t}=v\left(X_{t}\right) d t+a\left(X_{t}\right) d W_{t}$ which has the possibility to show default jump at a speed $h\left(X_{t}\right) \geq 0, W_{t}-$ geometric Brownian motion, $X$ is always strictly positive. We add two nonlocal volatility factors to the total diffusion: $a\left(X_{t}\right) \rightarrow a\left(X_{t}\right) f\left(Y_{t}, Z_{t}\right)$. The first factor $Y$ is dynamic. The second factor $Z$ changes slowly. So, our model is a multidimensional volatile stochastic model.

Let $(\Omega, F, P)$ denote probability space that supports correlated Brownian motion $\left(\mathrm{W}^{x}, \mathrm{~W}^{y}, W^{z}\right)$ and an exponential random variable $\varepsilon \sim \operatorname{Exp}(1)$, which is not independent of $\left(\mathrm{W}^{x}, \mathrm{~W}^{y}, W^{z}\right)$. We assume that the economy with three factors is described by homogeneous time, continuous Markov process $\chi=(\mathrm{X}, \mathrm{Y}, \mathrm{Z})$, which takes values in some state space $\mathrm{E}=I \times \mathrm{R} \times \mathrm{R}, I=\left(e_{1}, e_{2}\right),-\infty \leq e_{1}<e_{2} \leq \infty$. Suppose that $\chi$ begins in $E$ and instantly disappears once $X \notin I$, that is:

The dynamics of $\chi$ according to the physical value $\mathbb{P}$, is as follows:

$$
\chi_{t}=\left\{\begin{array}{ll}
\left(X_{t}, Y_{t}, Z_{t}\right), & \tau_{I}<t \\
\Delta, & \tau_{I}>t
\end{array}, \quad \tau_{I}=\inf \left(t>0: X_{t} \notin I\right),\right.
$$

where $(X, Y, Z)$ are assigned

$$
\left\{\begin{array}{c}
d X_{t}=v\left(X_{t}\right) d t+a\left(X_{t}\right) f\left(Y_{t}, Z_{t}\right) d W_{t}^{x} \\
d Y_{t}=\frac{1}{\epsilon} a_{11}\left(Y_{t}\right) d t+\frac{1}{\sqrt{\epsilon}} a_{12}\left(Y_{t}\right) d W_{t}^{y} \\
d Z_{t}=\delta a_{21}\left(Z_{t}\right) d t+\sqrt{\delta} a_{22}\left(Z_{t}\right) d W_{t}^{z} \\
d\left(W^{x}, W^{y}\right)_{t}=\rho_{x z} d t \\
d\left(W^{x}, W^{z}\right)_{t}=\rho_{x y} d t \\
d\left(W^{y}, W^{z}\right)_{t}=\rho_{y z} d t \\
\left(X_{0}, Y_{0}, Z_{0}\right)=(x, y, z) \in E .
\end{array}\right.
$$

where $\left(\rho_{x y}, \rho_{x z}, \rho_{y z}\right)$ such as $\left|\rho_{x y}\right|,\left|\rho_{x z}\right|,\left|\rho_{y z}\right| \leq 1$ and $1+2 \rho_{x y} \rho_{x z} \rho_{y z}-\rho_{x y}{ }^{2}-\rho_{x z}{ }^{2}-\rho_{y z}{ }^{2} \geq 0$, and matrix correlation of Brownian model is positive. The process $X$ can display, for instance, index value, short interest rates, option pricing. The physical value $\mathbb{P}$ of the process $X$, we consider as an instant drift $v\left(X_{t}\right)$ and stochastic volatility $a\left(X_{t}\right) f\left(Y_{t}, Z_{t}\right)>0$, which has two components: local $a\left(X_{t}\right)$ and nonlocal $f\left(Y_{t}, Z_{t}\right)$. Nonlocal volatility component $f\left(Y_{t}, Z_{t}\right)$ is based on two factors: $Y$ and $Z$, so for infinitesimal generators have

$$
\mathrm{M}_{Z}^{\epsilon}=\frac{1}{\epsilon}\left(\frac{1}{2} a_{12}^{2}(y) \partial_{y y}^{2}+a_{11}(y) \partial_{y}\right), \quad \mathrm{M}_{z}^{\delta}=\delta\left(\frac{1}{2} a_{22}^{2}(z) \partial_{z z}^{2}+a_{21}(z) \partial_{z}\right),
$$

Therefore, $Y$ and $Z$ have an internal timeline $\epsilon>0$ and $1 / \delta>0$. We assume that $\epsilon<<1$ and $\delta<<$ 1 , the internal timeline $Y$ is small, whereas the internal timeline $Z$ is large. So, $Y$ is volatility of fast variable factor, whereas $Z$ is vitality of a slow variable factor. Note that $\mathrm{M}_{Y}^{\epsilon}$ and $\mathrm{M}_{Z}^{\delta} \mathrm{t}$ are

$$
L=\frac{1}{2} a^{2}(x) \partial_{x x}^{2}+a_{1}(x) \partial_{x}-a_{2}(x), x \in\left(e_{1}, e_{2}\right)
$$


Suppose you have to pay share dividends $S_{t}=\mathbb{I}_{\{\tau>t\}} X_{t}, S>0$. then the state space $X$ will be $e_{1}, e_{2}=$ $(0, \infty)$. Consider a multidimensional diffusion process at Killing (default jumps) of constant variable model. In particular, $\widetilde{P}$ dynamics of $X$ default is set as

$$
d X_{t}=\left(\mu+c X_{t}^{2 \eta}\right) X_{t} d t+f\left(Y_{t}, Z_{t}\right) X_{t}^{\eta+1} d \widetilde{W}_{t}^{x}, \quad h\left(X_{t}\right)=\mu+c X_{t}^{2 \eta}
$$

To simplify calculations assume that the risk-free interest rates $r=0, \mu>0, c>0, Y$ and $Z$ are fast and slow variables of volatility, which are defined

$$
\left\{\begin{array}{c}
d X_{t}=\left(a_{1}\left(X_{t}\right)-a\left(X_{t}\right) f\left(Y_{t}, Z_{t}\right) \Omega\left(Y_{t}, Z_{t}\right)\right) d t+a\left(X_{t}\right) f\left(Y_{t}, Z_{t}\right) d \widetilde{W}_{t}^{x} \\
d Y_{t}=\left(\frac{1}{\epsilon} a_{11}\left(Y_{t}\right)-\frac{1}{\sqrt{\epsilon}} a_{12}\left(Y_{t}\right) \Lambda\left(Y_{t}, Z_{t}\right)\right) d t+\frac{1}{\sqrt{\epsilon}} a_{12}\left(Y_{t}\right) d \widetilde{W}_{t}^{y} \\
d Z_{t}=\left(\delta a_{21}\left(Z_{t}\right)-\sqrt{\delta} a_{22}\left(Z_{t}\right) \Gamma\left(Y_{t}, Z_{t}\right)\right) d t+\sqrt{\delta} a_{22}\left(Z_{t}\right) d \widetilde{W}_{t}^{z} \\
d\left\langle\widetilde{W}^{x}, \widetilde{W}^{y}\right\rangle_{t}=\rho_{x y} d t \\
d\left\langle\widetilde{W}^{x}, \widetilde{W}^{z}\right\rangle_{t}=\rho_{x z} d t \\
d\left\langle\widetilde{W}^{y}, \widetilde{W}^{z}\right\rangle_{t}=\rho_{y z} d t \\
\left(X_{0}, Y_{0}, Z_{0}\right)=(x, y, z) \in E
\end{array}\right.
$$

where

$$
\begin{aligned}
& d \widetilde{W}_{t}^{x}:= d W_{t}^{x}+\left(\frac{v\left(X_{t}\right)-b\left(X_{t}\right)}{a\left(X_{t}\right) f\left(Y_{t}, Z_{t}\right)}+\Omega\left(Y_{t}, Z_{t}\right)\right) d t \\
& d \widetilde{W}_{t}^{y}:=d W_{t}^{y}+\Lambda\left(Y_{t}, Z_{t}\right) d t \\
& d \widetilde{W}_{t}^{z}:=d W_{t}^{z}+\Gamma\left(Y_{t}, Z_{t}\right) d t
\end{aligned}
$$

In our study, there may be two possible ways of default when $X$ is beyond the time-frame $I$, or at random time $\tau_{h},\left(h\left(X_{t}\right) \geq 0\right.$ stochastic value (the so-called level of danger). Mathematically default time $\tau$ can be expressed as follows [2].

Volatility $X$ includes the local component $X_{t}^{\eta}$ and nonlocal component of multidimensionality $f\left(Y_{t}, Z_{t}\right)$. We assume, $\eta<0$, that is local volatility component $X_{t}^{\eta}$ increases when $X_{t}$, decreases. It means that prices and volatility have negative correlation. Stochastic danger level $h\left(X_{t}\right)$ increases when $X$ decreases. Now let's calculate the approximate price of European option for assets $S$. The European option price can be defined by the formula (2).

$$
\left\langle\mathrm{M}_{2}\right\rangle=\frac{1}{2} \bar{\sigma}^{2} x^{2 \eta+2} \partial_{x x}^{2}+\left(\mu+c x^{2 \eta}\right) x \partial_{x}-\left(\mu+c x^{2 \eta}\right),
$$

$\mathrm{M}_{2}$ - infinitesimal generator, the end of the time-frame that is the point $e_{2}=\infty$ is a natural border. However, the classification of point $e_{1}=0$ depends on the value $\eta$ and $c / \bar{\sigma}^{2}$. Therefore, we present the following classification:

1) $c / \bar{\sigma}^{2} \geq 1 / 2, \eta<0, e_{1}=0-$ trivial case,

2) $c / \bar{\sigma}^{2} \in(0,1 / 2), \eta \in\left[\frac{c}{\bar{\sigma}^{2}}-1 / 2,0\right), e_{1}=0$ - this number serves as the initial moment,

3) $c / \bar{\sigma}^{2} \in(0,1 / 2), \eta<\frac{c}{\bar{\sigma}^{2}}-\frac{1}{2}, e_{1}=0$ under such circumstances the start of time-frame is stable.

If parameters $(\mathrm{c}, \bar{\sigma}, \eta)$ are satisfying $c / \bar{\sigma}^{2} \in(0,1 / 2)$, and $\eta \in\left[\frac{c}{\bar{\sigma}^{2}}-\frac{1}{2}, 0\right), e_{1}=0$, then $e_{1}$ is considered as Killing border. To calculate the approximate price of the European option, we must find eigenfunctions $\left\{\psi_{n}\right\}$, eigenvalues $\left\{\lambda_{n}\right\}$ operator $\left\langle\mathrm{M}_{2}\right\rangle$. Note that $\left\langle\mathrm{M}_{2}\right\rangle$, presented in (2), looks like infinitesimal generator of the one-dimensional diffusion (1) with volatility $\bar{\sigma} a(x)$, deviation $\left(a_{1}(x)-\right.$ $\bar{f} \Omega a(x))$ and Killing $a_{2}(x), \operatorname{dom}\left(\left\langle\mathrm{M}_{2}\right\rangle\right)$ includes marginal conditions which are to be imposed at the end $e_{1}$ and $e_{2}$ equation $-\left\langle\mathrm{M}_{2}\right\rangle \psi_{n}=\lambda_{n} \psi_{n}, \psi_{n} \in \operatorname{dom}\left(\left\langle\mathrm{M}_{2}\right\rangle\right)$, at the interval $(0, \infty)$ with $\left\langle\mathrm{M}_{2}\right\rangle$ is defined as (5) follows 


$$
\lim _{x \rightarrow 0} \psi_{n}=0 \text {, if } \frac{c}{\bar{\sigma}^{2}} \in\left(0, \frac{1}{2}\right)
$$

\section{RESUlts}

The results of this research result from the article [2]

$$
\begin{gathered}
\psi_{n}=A^{\frac{v}{2}} \sqrt{\frac{(n-1) ! \mu}{\Gamma(v+n)}} x \exp \left(-A x^{-2 \eta}\right) L_{n-1}^{(v)}\left(A x^{-2 \eta}\right), \quad n=1,2,3, \ldots, \\
A=\frac{\mu}{\bar{\sigma}^{2}|\eta|}, \quad \lambda_{n}=2 \mu|\eta|(n+v), \quad v=\frac{1+2\left(\frac{2}{\bar{\sigma}^{2}}\right)}{2|\eta|},
\end{gathered}
$$

where $L_{n}^{(v)}=\sum_{i=0}^{n}(-1)^{i}\left(\begin{array}{c}n+v \\ n-i\end{array}\right)$ is the generalized Laguerre polynomials. Write expressions for the operators $\mathcal{A}$ and $\mathcal{B}$ :

$$
\mathcal{A}=-v_{3} x^{\eta+1} \partial_{x} x^{2 \eta+2} \partial_{x x}^{2}-v_{2} x^{2 \eta+2} \partial_{x x}^{2}, \quad \mathcal{B}=-v_{1} x^{\eta+1} \partial_{x}-v_{0}
$$

Analytical expressions for $\mathcal{A}_{k, n}, \mathcal{B}_{k, n}$ and $\widetilde{\mathcal{B}}_{k, n}$ can be obtained by making a change of variables [1] $A x^{-2 \eta} \rightarrow y$, using

$$
\partial_{y} L_{n}^{v}(y)=-L_{n-1}^{(v+1)}(y) \text { and } \int_{0}^{\infty} y^{\alpha} e^{-y} L_{n}^{(\alpha)}(y) L_{m}^{(\alpha)}(y) d y=\frac{\Gamma(n+\alpha+1)}{n !} \delta_{n m^{\prime}}
$$

where $\delta_{n m}-$ Kronecker symbol. Formulas for determining $\mathcal{A}_{k, n}, \mathcal{B}_{k, n} \mathrm{i} \widetilde{\mathcal{B}}_{k, n}$, have the following form [3]

$$
c_{n}=\left(\psi_{n}, 1\right)=\frac{2}{\bar{\sigma}} \sqrt{\frac{\pi}{\kappa}} \mathcal{N}_{n} A^{n} e^{-A^{2} / 4} .
$$

The European option profit with strike price $K>0$ can be decomposed as follows [9]:

$$
\left(K-S_{t}\right)^{+}=\left(K-X_{t}\right)^{+} \mathbb{1}_{\{\tau>t\}}+K\left(1-\mathbb{1}_{\{\tau>t\}}\right) .
$$

The first item on the right hand side (3) profit option is submitted to default at time $t$. The second item is profit option which is submitted after the default, which occurs at time $t$. So, the value of the option with strike price $K$ - is denoted as $u^{\epsilon, \delta}(t, x ; K)$ and can be expressed as the sum of:

$$
u^{\epsilon, \delta}(t, x ; K)=u_{o}^{\epsilon, \delta}(t, x ; K)+u_{D}^{\epsilon, \delta}(t, x ; K)
$$

where

$$
\begin{gathered}
u_{o}^{\epsilon, \delta}(t, x ; K)=\widetilde{\mathbb{E}}_{x, y, z}\left[\left(K-X_{t}\right)^{+} \mathbb{1}_{\{\tau>t\}}\right], \\
u_{D}^{\epsilon, \delta}(t, x ; K)=K-K \widetilde{\mathbb{E}}_{x, y, z}\left[\mathbb{1}_{\{\tau>t\}}\right]=K-K \int_{0}^{\infty} \widetilde{\mathbb{E}}_{x, y, z}\left[\delta_{x^{\prime}}\left(X_{t}\right) \mathbb{1}_{\{\tau>t\}}\right] d x^{\prime} \\
=K-K \int_{0}^{\infty} u_{1}^{\epsilon, \delta}\left(t, x ; x^{\prime}\right) d x^{\prime}, \\
u_{1}^{\epsilon, \delta}\left(t, x ; x^{\prime}\right)=\widetilde{\mathbb{E}}_{x, y, z}\left[\delta_{x^{\prime}}\left(X_{t}\right) \mathbb{1}_{\{\tau>t\}}\right], \quad 1 \notin L^{2}\left(\mathbb{R}^{+}, \mathfrak{m}\right)
\end{gathered}
$$

We used that $1=\int_{0}^{\infty} \delta_{x^{\prime}}\left(X_{t}\right) d x^{\prime}$ on the set $\{\tau>T\}$.

So, as the functions of profit $H_{0}(x)=(K-x)^{+}$and $H_{1}(x)=\delta_{x^{\prime}}(x)$ are $L^{2}\left(\mathbb{R}^{+}, \mathfrak{m}\right)$, we can calculate:

$$
c_{0, n}=\left(\psi_{n}(\cdot),(k-\cdot)^{+}\right), \quad c_{1, n}=\left(\psi_{n}, \delta_{x^{\prime}}\right) .
$$

Expressions for $c_{0, n}$ and $c_{1, n}$ can be found in [10]. 
The estimated value of the European option can now be calculated using the theorems 1, 2, 3 [2].

For the European variant the option volatility $I^{\epsilon, \delta}$ with price $u^{\epsilon, \delta}(t, x ; K)$ is determined by using

$$
u^{\epsilon, \delta}(t, x ; K)=u^{B S}\left(t, x, I^{\epsilon, \delta} ; K\right)
$$

where $u^{B S}\left(t, x, I^{\epsilon, \delta} ; K\right)$ Black-Scholes price with volatility $I^{\epsilon, \delta}$.

The calculation results are presented in Figure 1
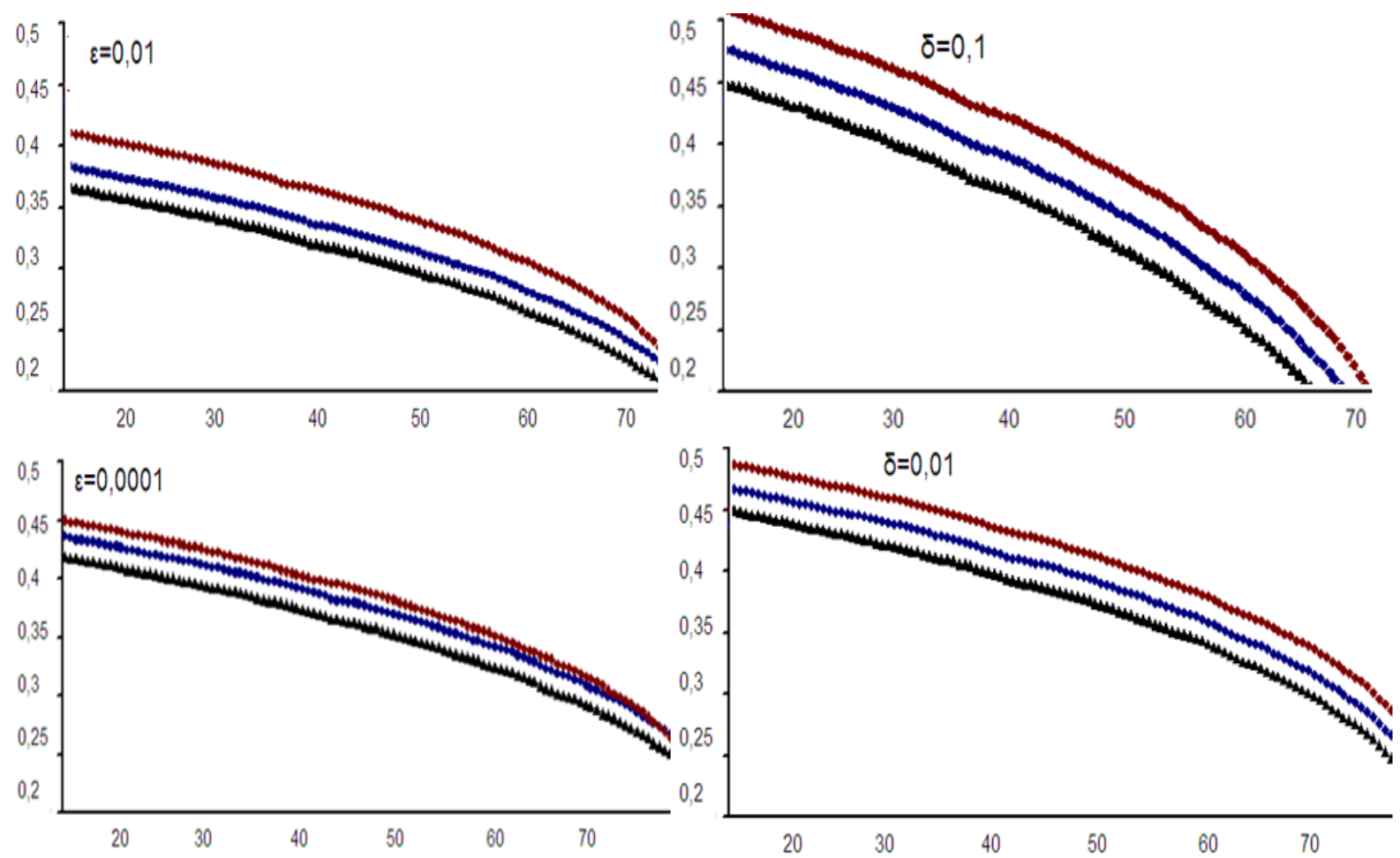

$\bullet$ volatility of the fast variables $₫$ volatility of the full cost $\multimap-$ volatility of the slow variables

Fig. 1. Volatility Dynamics

Volatility is constructed on the left hand side of Figure 1 depends on the price, the option for the model, which has only volatility of the fast variables. Dynamics $Y$ and volatility function $f$ are defined by the formula.

$$
\begin{gathered}
d Y_{t}=\left(-\frac{1}{\epsilon} Y_{t}-\frac{1}{\sqrt{\epsilon}} a_{12} \operatorname{Er} f\left(Y_{t}\right)\right) d t+a_{12} d \widetilde{W}_{t}^{y}, \quad f\left(Y_{t}\right)=\frac{\sigma \exp \left(Y_{t}\right)}{\exp \left(-\frac{a_{12}^{2}}{2}\right)} \\
\operatorname{Erf}(y):=\frac{2}{\sqrt{\pi}} \int_{0}^{y} e^{-t^{2}} d t .
\end{gathered}
$$

Volatility was built for comparison of full value $u^{\epsilon}$ and on the right hand side of Figure 1 is shown volatility caused by approximate price, the option for the model with volatility of the slow variables. Dynamics $Z$ and volatility function $f$ are set

$$
d Z_{t}=\left(-\delta Z_{t}-\sqrt{\delta} a_{22} \operatorname{Erf}\left(Z_{t}\right)\right) d t+a_{22} d \widetilde{W}_{t}^{z}, \quad f\left(Z_{t}\right)=\frac{\sigma \exp \left(Z_{t}\right)}{\exp (z)}
$$

As expected, $\varepsilon$ and $\delta$ which move to the zero, volatility moves to volatility price implied by full value. 


\section{CONCLUSIONS}

This paper, extends the method of finding approximate price for a wide range of derivative assets. One of the main advantages of our pricing methodology is that by combining methods of the spectral theory of singular and regular perturbance, the calculation of asset prices leads to solving the equation by eigenvalues and eigenfuntion methods as well as by solving Poisson equation. Once this equation is solved, the approximate price of a derivative asset may be calculated formulaically.

Price finding is reduced to the problem solving of eigenvalues and eigenfunctions of a certain equation. The main advantage of our pricing methodology is that, by combining methods in spectral theory, regular perturbation theory, and singular perturbation theory, we reduce everything to equations to find eigenfunctions and eigenvalues.

\section{REFERENCES}

[1] Burtnyak I.V. and Malytska A.P. The Investigation of Securities Cost Using Methods of Spectral Analysis. International Journal of Economic Research, 14 (15) (2017), 705-715.

[2] Burtnyak I.V. and Malytska A.P. Spectral study of options based on CEV model with multidimensional volatility. Investment Management and Financial Innovations, 15 (1) (2018), 18-25. doi: 10.21511/imfi.15(1).2018.03

[3] Cox J. Notes on Option Pricing I: Constant Elasticity of Diffusions. Unpublished draft, Stanford University, 1975.

[4] Davydov D., Linetsky, V. Structuring, Pricing and Hedging Double-barrier Step Options. Journal of Computational Finance, 5 (2) (2001), 55-88.

[5] Fouque J-P., Papanicolaou G., and Sircar R. Derivatives in Financial Markets with Stochastic Volatility. Cambridge University Press, 2000.

[6] Gatheral J. The Volatility Surface: a Practitioner's Guide. John Wiley and Sons, Hoboken, New Jersey, 2006.

[7] Goldstein R.S., Keirstead W.P. On the Term Structure of Interest Rates in the Presence of Reflecting and Absorbing Boundaries. SSRN, (1997). doi: 10.2139/ssrn.19840

[8] Lewis A. Applications of Eigenfunction Expansions in Continuous-time Finance. Mathematical Finance, 8 (4) (1998), 349-383. doi: 10.1111/1467-9965.00059

[9] Linetsky V. Lookback Options and Diffusion Hitting Times: A Spectral Expansion Approach. Finance and Stochastics, 8 (3) (2004), 373-398. doi: 10.1007/s00780-003-0120-5

[10] Lorig M. Pricing Derivatives on Multiscale Diffusions: An Eigenfunction Expansion Approach. Mathematical Finance, 24 (2) (2014), 331 -363. doi: 10.1111/mafi.12007

[11] Pelsser, A. Pricing Double Barrier Options Using Laplace Transforms. Finance and Stochastics, 4 (1) (2000), 95-104. doi: 10.1007/s007800050005

Address: Ivan Burtnyak, Anna Malytska, Vasyl Stefanyk Precarpathian National University, 57, Shevchenko Str., Ivano-Frankivsk, 76018, Ukraine.

E-mail: ivan.burtnyak@pnu.edu.ua

Received: 10.09.2019; revised: 04.12.2019. 
Буртняк Іван, Малицька Ганна. CEV модель стохастичної волатильності. Журнал Прикарпатського університету імені Василя Стефаника, 6 (3-4) (2019), 22-28.

У цій роботі розроблено систематичний метод розрахунку наближених цін для великого спектру цінних паперів, що передбачає використання інструментів спектрального аналізу, сингулярної та регулярної теорії збурень. Ціни деривативів залежать від стохастичної волатильності, яка може бути багатовимірною, в тому сенсі, що вона може бути обумовлена одним швидкозмінним і одним повільно змінним фактором. Знайдена наближена ціна двобар'єрних опціонів 3 багатофакторною. Встановлено теорему оцінки точності наближення цін опціонів. Знайдені явні формули для знаходження значення похідних цінних паперів, що грунтуються на застосуванні власних фун кцій та власних значень самоспряжених операторів з використанням крайових задач ддя сингулярних та регулярних збурень. У цій статті розроблено загальний метод отримання орієнтовної ціни для широкого класу цінних паперів. Розроблена загальна теорія оцінки ціни деривативів, породжених дифузійними процесами. Наведено алгоритм розрахунку наближеного рівня цін опціонів. Встановлюється точність наближення. Розроблена теорія застосовується до дифузійного оператора, який розкладається за власними функціями та власними значеннями. Мета статті розробити алгоритм пошуку наближеної ціни деривативів та знайти точні формуди знаходження значень похідних цінних паперів на основі знаходження власних функцій та власних значень самоспряжених операторів з використанням граничних значень для сингулярних і регулярних збурень. Знаходження цін деривативів зводиться до розв'язування задач на знаходження власних значень та власних функцій певного рівняння. Основна перевага нашої методології ціноутворення полягає в тому, що, поєднуючи методи спектральної теорії, регулярної теорії збурень та сингулярної теорії збурень, ми зводимо все до розв'язання рівнянь, які дають можливість для пошуку власних функцій та власних значень операторів.

Кдючові слова: ціноутворення деривативів, стохастична волатильність, волатильність, спектральна теорія, сингулярна теорія збурень, регулярна теорія збурень.

локальна 